\title{
Estimates of genetic parameters for oleoresin and growth traits in juvenile loblolly pine
}

\author{
James H. Roberds, Brian L. Strom, Fred P. Hain, David P. Gwaze, \\ Steven E. McKeand, and Larry H. Lott
}

\begin{abstract}
In southern pines of the United States, resistance to attack by southern pine beetle, Dendroctonus frontalis Zimmermann, is believed to principally involve flow of oleoresin to beetle attack sites. Both environmental and genetic factors are known to affect the quantity of oleoresin flow in loblolly pine, Pinus taeda L., but little is known about the genetic contribution to phenotypic variation in this trait. Here we report estimates of genetic variation in oleoresin flow and growth traits for a population of this species. Oleoresin yield, total height, and diameter were measured on 10- and 11-year-old trees from an experimental test in Santa Rosa County, Florida. Trees were from 72 full-sib families produced by mating 48 parents according to a disconnected partial diallel mating design. Resin yield was determined from breast-height samples collected at two times: once in the summer of 1999 when latewood was being produced (summer resin flow), and once in the spring of 2000 during earlywood formation (spring resin flow). All traits studied were found to be highly genetically variable and to have much greater additive than dominance variance. Estimates of narrow-sense heritability for spring and summer resin flow were in the moderate range and are comparable to values obtained for the growth traits. Additive genetic correlations between oleoresin yield and the growth traits were positive and moderately high, suggesting that directional selection to improve growth in loblolly pine will also result in increased production of oleoresin.
\end{abstract}

Résumé : Chez les pins du Sud des États-Unis, on croit que la résistance aux attaques du dendroctone méridional du pin (Dendroctonus frontalis Zimmermann) s'exprime principalement par un écoulement d'oléorésine dans les sites d'attaque du dendroctone. On sait que les facteurs environnementaux et génétiques influencent l'importance de l'écoulement d'oléorésine chez le pin à encens (Pinus taeda L.). Cependant, la part de la variation phénotypique qui est d'origine génétique chez ce caractère est peu connue. Cette étude fait état d'estimations de la variation génétique pour les caractères de croissance et d'écoulement d'oléorésine dans une population de cette espèce. La production d'oléorésine, la hauteur totale et le diamètre ont été mesurés sur des arbres de 10 et 11 ans faisant partie d'un test expérimental situé dans le comté de Santa Rosa, en Floride. Les arbres étaient représentatifs de 72 familles biparentales issues de croisements entre 48 parents selon un plan de croisements diallèle partiel disjoint. La production de résine a été déterminée à partir d'échantillons pris à hauteur de poitrine et récoltés à deux reprises : une fois durant l'été de 1999 durant la formation du bois d'été (écoulement estival d'oléorésine) et une fois au printemps de l'an 2000 durant la formation du bois de printemps (écoulement printanier d'oléorésine). Tous les caractères étudiés ont démontré une forte variabilité génétique ainsi qu'une variance additive beaucoup plus grande que la variance de dominance. Les estimations d'héritabilité au sens strict pour les écoulements printanier et estival d'oléorésine étaient d'amplitude modérée et comparables aux valeurs obtenues pour les caractères de croissance. Les corrélations génétiques additives entre la production d'oléorésine et les caractères de croissance étaient positives et modérément élevées, suggérant que la sélection dirigée en vue d'améliorer la croissance du pin à encens se traduira également par une production accrue d'oléorésine.

[Traduit par la Rédaction]

\section{Introduction}

Flow of oleoresin is thought to be a primary means of defense utilized by trees in the genus Pinus to resist attack by bark beetles. In pines of the southeastern United States, trees that produce large quantities of constitutive oleoresin, resin formed in the absence of an exogenous stimulus, appear to be most capable of preventing or impeding infestation by

Received 3 April 2003. Accepted 31 July 2003. Published on the NRC Research Press Web site at http://cjfr.nrc.ca on 12 December 2003.

J.H. Roberds ${ }^{1}$ and L.H. Lott. USDA Forest Service, Southern Research Station, Southern Institute of Forest Genetics, 23332 Highway 67, Saucier, MS 39574-9344, U.S.A.

B.L. Strom. USDA Forest Service, Southern Research Station, Alexandria Forestry Center, 2500 Shreveport Highway, Pineville, LA 71360-2009, U.S.A.

F.P. Hain. North Carolina State University, Department of Entomology, Box 7626, Raleigh, NC 27695-7626, U.S.A.

D.P. Gwaze. Texas Forest Service, Texas A\&M University, Forest Science Laboratory, College Station, TX 77843-2585, U.S.A.

S.E. McKeand. North Carolina State University, Department of Forestry, Box 8002, Raleigh, NC 27695-8002, U.S.A.

${ }^{1}$ Corresponding author (e-mail: jroberds@fs.fed.us). 
southern pine beetle (SPB), Dendroctonus frontalis Zimmermann, the most destructive insect pest in pine forests of this region (Hodges et al. 1979; Cook and Hain 1987; Reeve et al. 1995; Strom et al. 2002). Abundant resin flow is believed to deter SPB invasion in two principal ways: (1) by serving as a wound cleansing agent that expels or entraps attacking beetles, thus precluding or halting gallery formation (Cook and Hain 1987; Popp et al. 1991), and (2) by enhanced delivery of toxic compounds to attack sites (Coyne and Lott 1976). Moreover, it is also possible that bountiful resin flow contributes to semiochemical-based tree resistance (Strom et al. 2002). Apart from tree defense, high resin flow also acts to retard beetle reproductive success (Reeve et al. 1995).

Genetic and environmental factors are both known to influence the quantity of constitutive resin produced by loblolly pine trees, Pinus taeda L. (Lorio 1986; Nebeker et al. 1988, 1992; Lorio et al. 1990; Blanche et al. 1992; Wilkens et al. 1998; Lombardero et al. 2000). Most of the attention devoted to identification of variables that have a bearing on resin production, however, has concentrated on environmental attributes and cultural practices aimed at stimulating tree growth. A prominent focus of this research includes potential determinants that might alter resin production over the course of a growing season, including those that can cause carbon resources to be shifted to secondary metabolic processes involved in oleoresin synthesis away from the dominant primary processes that contribute to tree growth. Allocation of photosynthates to primary and secondary metabolic processes is believed to result in a trade-off between growth and resin formation following plant growthdifferentiation principles formulated first by Loomis (1932) and later modified to explain the relationship between growth and resin flow in pines by Lorio (1986).

In contrast, relatively meager effort has been committed to determining how strongly genetic effects influence phenotypic variation for resin yield in loblolly pine. Research has demonstrated that large differences occur among full-sib families in amounts of constitutive flow (Nebeker et al. 1992). Moreover, wind-pollinated progeny of trees that survived in stands heavily infested by SPB have been shown to possess greater resin flow than comparable trees from a control population (Strom et al. 2002). Genetic variation, however, has not been previously estimated and characterized in P. taeda, even though substantial genetic variation has been found to exist in resin producing ability in species worked for naval stores. Analyses by Squillace and Bengston (1961) suggest that narrow-sense heritability for gum resin yield in slash pine (Pinus elliottii Engelm. var. elliottii) is around 0.55, indicating that this trait is under fairly strong genetic control. Support is also provided by a selection experiment designed to assess the efficacy of directional selection as a means to improve resin production in $P$. elliottii. The first generation of selection resulted in increased tree yields $>60 \%$ (McReynolds and Gansel 1985). Experimental observations in maritime pine (Pinus pinaster Ait.) likewise indicate that resin-yielding capability is under substantial genetic regulation in that species (Tadesse et al. 2001).

Because of the significant role of constitutive resin flow in defense against attack by SPB, and findings that suggest considerable genetic variation exists for this trait in loblolly pine, reliable estimates of genetic variation occurring in pop- ulations for constitutive resin yield are needed. Here we report estimates of genetic and phenotypic variation in juvenile resin yield and tree growth traits in a population of young loblolly pine. As genetic and phenotypic associations between resin yielding ability and growth traits are items of considerable interest, both from evolutionary and breeding perspectives, we present estimates of genetic, phenotypic, and environmental correlations between these traits as well.

\section{Materials and methods}

\section{Experimental material}

Total resin flow and growth measurements were taken on trees in a progeny trial located in Santa Rosa County, Florida. This trial is part of a series of trials conducted by International Paper Company in cooperation with the North Carolina State University - Industry Cooperative Tree Improvement Program as a component of a breeding program designed to improve loblolly pine for planting in the lower Gulf Coastal Plain of the southeastern United States. Progeny included were produced by mating parent trees selected for exceptional growth and form, primarily from plantations in the coastal plain of west-central Georgia, western Florida, and southern Alabama and Mississippi. During the first growing season, trees in the trial were fertilized with a single application of diammonium phosphate applied at a rate of $227 \mathrm{~g} /$ tree. In addition, herbicide was applied during the first two years to control herbaceous vegetation. Trees in our study are from family plots that are a subset of the plots in this trial.

Progenies in this experiment make up a complement of full-sib families formed by intercrossing parents in a pattern determined by a disconnected diallel mating design. The particular design used incorporates eight separate balanced partial diallels. Each component partial diallel design is composed of matings among six parents in a balanced arrangement so that each parent is crossed three times without inclusion of reciprocal crosses in a pattern described in Kempthorne and Curnow (1961) and Braaten (1965). The experimental material thus consists of progeny from 72 fullsib families derived from crosses among 48 parents.

Field plots in the experiment were established as row plots in a replication-in-blocks incomplete-block experimental design. Rows were spaced $3.7 \mathrm{~m}$ apart, and trees were planted $2.1 \mathrm{~m}$ apart within rows. There are four incomplete blocks, each composed of plots for six replications. Two of the blocks were established in the spring of 1989 and two in the spring of 1990. They occupy adjacent areas on a site that was an agricultural field prior to establishment of the trial. Each block contains family plots for two disconnected diallels. In this way we coupled a balanced partial diallel mating design with an incomplete-block experimental design in the manner described by Braaten (1965). Plot size varied from one to three trees with $>70 \%$ of the plots having three trees. Trees judged to have moderate and severe bole fusiform rust infections were excluded from analysis. In total, measurements for 1131 trees are included in our analyses.

\section{Traits evaluated}

Total tree height and diameter at breast height (DBH) were measured in autumn of 1999 and winter of 2000, re- 
spectively, after trees had completed 10 or 11 growing seasons. Total tree volume was computed from a volume equation developed for young loblolly plantations growing in the Gulf Coastal Plain of the United States (Schmitt and Bower 1970).

Two oleoresin flow measurements were taken: one in the first week of September 1999 when trees were assumed to be producing latewood (summer flow) and one in the first week in May 2000 during the time of earlywood production (spring flow) (Lorio et al. 1990). At each measurement two resin samples, each from a $1.27 \mathrm{~cm}$ diameter wound, were collected from each tree with the mean mass of the samples being used to represent tree resin yield. Samples were taken from opposing positions at breast height over $24 \mathrm{~h}( \pm 1.5 \mathrm{~h})$ using the method described in Strom et al. (2002), except that exuding resin was directed into rubber balloons rather than open vials to avoid rain contamination.

\section{Statistical analysis}

Means and variance descriptive statistics were computed using PROC INSIGHT (release 8.1 for Windows, SAS Institute Inc., Cary, N.C.), and differences among full-sib family means were evaluated using the likelihood ratio test. Test values were generated from mixed-model analyses using PROC MIXED in SAS. Because the resin yield data were strongly skewed toward the right (see discussion in the Results and Discussion sections), they were transformed using the function $\log _{\mathrm{e}}(Y+0.2)$ prior to these analyses, whereas growth data were analyzed untransformed.

Currently, little is known about the distributional properties for resin flow values occurring among trees in even-aged populations of loblolly pine at specific times during the annual growing season. Preliminary examination of our observations suggested that resin yield values might follow a gamma distribution. Accordingly, we tested frequencies observed for resin flow classes to determine whether they approximately fit gamma distributions:

$$
f(x)=\frac{1}{\beta^{\alpha} \Gamma(\alpha)} x^{\alpha-1} \mathrm{e}^{-(x / \beta)}
$$

Maximum likelihood estimates for parameters $\alpha$ and $\beta$ were computed (PROC CAPABILITY, release 8.1 for Windows, SAS Institute Inc., Cary, N.C.) separately from data collected in the 1989 and 1990 plantings for both spring and summer resin flow (four distributions fitted). Three obvious outlier points were removed prior to fitting the distributions. Observed distributions were then tested against the fitted distributions using $\chi^{2}$ goodness-of-fit tests.

Variance and covariance components were estimated in analyses based upon the following linear model for individual trees:

$$
Y_{i j k l}=\mu+b_{i}+r_{j(i)}+f_{k(i)}+r f_{j k(i)}+a_{l(i j k)}+\varepsilon_{i j k l}
$$

where $Y_{i j k l}$ is an observation on the $l$ th individual in the plot for the $k$ th family in the $j$ th replication of the $i$ th incomplete block, $\mu$ is the population mean, $b_{i}$ is the block effect, $r_{j(i)}$ is the replication effect within the $i$ th block, $f_{k(i)}$ is the family effect within the $i$ th block, $r f_{j k(i)}$ is the replication by family interaction effect within the $i$ th block, $a_{l(i j k)}$ is the additive genetic effect for individual trees in the plot for the $k$ th fam- ily in the $j$ th replication of the $i$ th block, and $\varepsilon_{i j k l}$ is the within-plot error effect. In this model, error effects are assumed to be normally distributed with mean of zero and variance of $\sigma^{2}$, and all effects are assumed to be random except the mean, which is considered fixed. For the replication-in-blocks design used in our experiment, blocks are confounded with differences among pairs of diallels, since each block contains families from a different pair of diallels. Therefore in our analyses, replication, family, replication by family, and additive genetic effects were treated as nested within blocks. Within each block, however, families from the two component diallels were randomly assigned to plots irrespective of diallel identity. As a result, it was not necessary to break out a diallels-in-blocks component in our analyses.

Variances and covariances for the random effects in the model were estimated using the REML procedure in the software package ASREML (Gilmour 1996). Because additive genetic effects are accounted for independent of family effects and additive genetic variance is estimated in ASREML as the variance of breeding values computed for each individual represented in pedigrees, either as a parent or offspring, the family variance component contains only nonadditive genetic variance and is identical to specific combining ability variance. Additional details concerning use of the individual tree model for estimation of genetic variances and covariances can be found in Gwaze et al. (2002). We assume that epistatic genetic effects in the population of inference are negligible, and as a consequence, family variance $\left(\sigma_{\mathrm{f}}^{2}\right)$ in this population is approximately equal to $1 / 4 \sigma_{\mathrm{D}}^{2}$, where $\sigma_{\mathrm{D}}^{2}$ represents dominance genetic variance. Thus dominance variance was estimated as $\hat{\sigma}_{\mathrm{D}}^{2}=4 \hat{\sigma}_{\mathrm{f}}^{2}$, where carets indicate estimates.

Genetic and phenotypic variances, both broad-sense $(\hat{H})$ and narrow-sense $\left(\hat{h}^{2}\right)$ heritabilities computed on an individual-tree basis, and ratios of dominance to phenotypic variance $(\hat{D})$ were estimated in univariate analyses, while additive genetic $\left(r_{\mathrm{A}}\right)$ and phenotypic $\left(r_{\mathrm{P}}\right)$ correlations were estimated in bivariate analyses. Broad-sense heritabilities were estimated as the sum of $\hat{h}^{2}$ and $\hat{D}$. Standard errors for estimates of narrow-sense heritability, ratios of dominance to phenotypic variance, and the additive genetic and phenotypic correlations were obtained from ASREML. Approximation formulas for variances of ratios and correlation coefficients used in these determinations are given in Gilmour et al. (1999).

To evaluate the influence of environmental factors acting within individuals on phenotypic correlations, we investigated environmental correlations between traits. These were estimated as

$$
\hat{r}_{\mathrm{E}}=\frac{\hat{\sigma}_{\mathrm{E}}(a, b)}{\hat{\sigma}_{\mathrm{E}}(a) \times \hat{\sigma}_{\mathrm{E}}(b)}
$$

where $\hat{\sigma}_{\mathrm{E}}(a)$ and $\hat{\sigma}_{\mathrm{E}}(b)$ are estimates for the environmental standard deviations for traits $a$ and $b$, respectively, and $\hat{\sigma}_{\mathrm{E}}(a, b)$ is the estimate for the environmental covariance between the two traits for the same tree (Lynch and Walsh 1998). Estimates for this covariance could not be directly obtained from available computer software; hence they were determined from

$$
\hat{\sigma}_{\mathrm{E}}(a, b)=\left[\hat{\sigma}_{\mathrm{E}}^{2}(a+b)-\hat{\sigma}_{\mathrm{E}}^{2}(a)-\hat{\sigma}_{\mathrm{E}}^{2}(b)\right] / 2
$$


where $\hat{\sigma}_{\mathrm{E}}(a+b)$ is the estimate for the environmental variance for the sum of the two traits for the same individual. The variances included in this computation were obtained from the linear combination $\hat{\sigma}_{\mathrm{E}}^{2}=-2 \hat{\sigma}_{\mathrm{GCA}}^{2}-3 \hat{\sigma}_{\mathrm{SCA}}^{2}+\hat{\sigma}_{\mathrm{rf}}^{2}+\hat{\sigma}_{\mathrm{e}}^{2}$, where $\hat{\sigma}_{\mathrm{GCA}}^{2}, \hat{\sigma}_{\mathrm{SCA}}^{2}, \hat{\sigma}_{\mathrm{rf}}^{2}$, and $\hat{\sigma}_{\mathrm{e}}^{2}$ are general combining ability, specific combining ability, replication by family interaction, and error variance component estimates, respectively, obtained from mixed-model analyses using the computer program GAREML (Huber 1993). It should be pointed out that environmental correlations estimated in this way are not affected by within-locus dominance effects, as these have been removed by the estimation procedure. Contributions from residual epistatic effects, however, are included if these effects exist.

One goal of this research is to obtain estimates of standardized measures of genetic variance so that genetic variances in resin yield can be compared across populations in the future, and so that genetic variances can properly be compared across traits. As the additive genetic coefficient of variation has been shown to be superior to heritability as a standardized measure of additive genetic variability for such comparisons (Houle 1992), we estimated additive genetic coefficients of variation using the estimator $\mathrm{CV}_{\mathrm{A}}=$ $100\left(\hat{\sigma}_{\mathrm{A}}^{2}\right)^{1 / 2} / \bar{x}$, where $\bar{x}$ represents the estimate for the trait mean. Since we are also interested in making similar comparisons among dominance variances, dominance genetic coefficients of variation, $\mathrm{CV}_{\mathrm{D}}$, were likewise estimated. Means in these determinations were adjusted to reflect values at age 10. For this purpose, we used weighted means computed between the means for 10-year-old trees and the product of 10/11 times the means for 11-year-old trees.

Parameter estimates were obtained from data collected on both the 10- and 11-year-old blocks. Main effects associated with age differences were accounted for as a component of block effects and thus do not affect estimates obtained for the genetic and phenotypic variances and covariances. Nevertheless, for estimates derived from such a composite collection of data to be properly interpreted, it is necessary to assume that populations of 10- and 11-year-old trees have identical or nearly equal variances and covariances. There is at least one piece of evidence to suggest that this is a reasonable approximation for height in populations of young loblolly pine with a similar age profile as our experimental material. In an investigation of genetic variation in a southwest Georgia population, Balocchi et al. (1993) report estimates of genetic and phenotypic variances and genetic covariances for height at ages 9 and 10 that do not differ appreciably. We assume that the approximation also holds for the other traits.

\section{Results}

\section{Descriptive statistics}

Means and measures of variation by age of trees are shown in Table 1. Estimates are based on 589 observations in the 1989 blocks and 542 observations in the 1990 blocks. Tree growth in the experimental plots, while not exceptional, was very good, greater than $1 \mathrm{~m} /$ year in height and more than $1.7 \mathrm{~cm} /$ year in diameter. These rates demonstrate that natural features plus the cultural treatments administered combine to make the experimental site a good environment for growing loblolly pine. Mean resin yields range from $1.28 \mathrm{~g} /$ wound for summer flow in the age 10 blocks to just under $2.0 \mathrm{~g} /$ wound for spring resin flow in the same blocks. In blocks of both ages, means for spring resin flow are slightly higher than means for summer flow. Coefficients of variation $(\mathrm{CV})$ for the flow traits are substantially larger than those for the growth traits, indicating that greater variation occurs among trees in the resin yield traits.

\section{Distribution of oleoresin flow}

Tree resin flow yields were approximately distributed as gamma random variables. Estimates of parameters for fitted gamma distributions and $\chi^{2}$ goodness-of-fit statistics are presented in Table 2. Data for both summer and spring resin flow in the two sample populations fit gamma distributions reasonably well. Observed and fitted distributions for summer resin flow in the 1989 plantings are illustrated in Fig. 1. Since $\beta=\sigma^{2} / \mu$, where $\mu$ and $\sigma^{2}$ represent mean and variance for the gamma distribution, respectively, and values estimated for $\beta$ fall in the interval 0.50 to 0.75 , variances in the fitted distributions are less than three-quarters of the distribution means. For gamma distributions, $\mathrm{CV}=100 \alpha^{-1 / 2}$; thus for the range of values estimated for $\alpha$, fitted distributions have CV's extending from 55.9 to 64.8 . These values correspond well with those computed from the observed samples (Table 1). Estimates of $\alpha$ obtained for spring flow are higher than those for summer flow in blocks of both ages, but as these differences were not tested, it is not clear whether they indicate the presence of a trend for greater $\alpha$ values in spring flow.

\section{Variance components and derivative genetic parameters}

Estimates of variances and allied statistics for contributing sources of variability are presented for each trait in Table 3. Several general patterns that apply to both resin flow and growth traits are evident regarding partitioning of the phenotypic variance. First, broad-sense heritability, the proportion of phenotypic variance attributable to genetic sources, is estimated to be greater than 0.5 for each trait. This means that genetic effects are the primary factors contributing to the phenotypic variability observed. The paramount role that genetic effects have in shaping phenotypic variation is also indicated by the large differences observed among full-sib family means. In likelihood ratio tests conducted to determine whether variation exists among full-sib families, $\chi^{2}$ test values (one degree of freedom) extend among traits from a low of 113.512 for DBH to a high of 192.767 for summer resin flow. Tests for all traits indicate highly significant differences among family means $(p<0.0001)$. Second, estimates of additive genetic variance are substantially larger than those for dominance variance, indicating that among the genetic components, additive effects predominate in influencing phenotypic variance. Third, environmental variance, estimated by subtracting the genetic components from phenotypic variance, is found to be lower than additive variance but greater than dominance variance. Such a pattern clearly demonstrates that over the field microenvironments encountered in our experiment, additive genetic effects are the principal factors contributing to phenotypic variability 
Table 1. Basic statistics for resin flow and growth traits by age of test blocks.

\begin{tabular}{|c|c|c|c|c|c|c|}
\hline \multirow[b]{2}{*}{ Trait } & \multicolumn{3}{|c|}{1989 blocks (age 11) } & \multicolumn{3}{|c|}{1990 blocks (age 10) } \\
\hline & Mean & SD & $\mathrm{CV}$ & Mean & SD & $\mathrm{CV}$ \\
\hline Summer resin flow $(\mathrm{g})$ & 1.73 & 1.15 & 66.5 & 1.28 & 0.85 & 66.3 \\
\hline Spring resin flow $(\mathrm{g})$ & 1.88 & 1.12 & 59.9 & 1.92 & 1.25 & 65.0 \\
\hline Total height (m) & 12.59 & 1.37 & 10.9 & 12.13 & 1.07 & 8.8 \\
\hline $\mathrm{DBH}(\mathrm{cm})$ & 18.91 & 3.01 & 15.9 & 17.74 & 2.55 & 14.4 \\
\hline Volume $\left(\mathrm{m}^{3}\right)$ & 0.143 & 0.053 & 37.3 & 0.120 & 0.039 & 32.5 \\
\hline
\end{tabular}

Note: SD, standard deviation; $\mathrm{CV}$, coefficient of variation.

Table 2. Maximum likelihood estimates of parameters for gamma distributions fitted from resin flow data.

\begin{tabular}{|c|c|c|c|c|c|c|}
\hline \multirow[b]{2}{*}{ Trait } & \multirow[b]{2}{*}{$N^{*}$} & \multicolumn{2}{|c|}{ Gamma parameters } & \multicolumn{3}{|c|}{ Goodness-of-fit test statistics } \\
\hline & & $\alpha$ & $\beta$ & $\chi^{2}$ & df & Probability \\
\hline \multicolumn{7}{|l|}{1989 blocks } \\
\hline Summer resin flow & 589 & 2.3839 & 0.7258 & 4.0790 & 9 & 0.908 \\
\hline Spring resin flow & 588 & 3.2000 & 0.5823 & 15.4440 & 10 & 0.117 \\
\hline \multicolumn{7}{|l|}{1990 blocks } \\
\hline Summer resin flow & 541 & 2.5402 & 0.4977 & 13.0803 & 10 & 0.218 \\
\hline Spring resin flow & 541 & 2.7730 & 0.6878 & 15.4608 & 9 & 0.079 \\
\hline
\end{tabular}

$* N$ is the number of observations.

Fig. 1. Distribution of summer oleoresin flow for 11-year-old trees. The histogram represents the observed frequency distribution for breast-height samples from 589 trees. The continuous curve represents the gamma distribution $(\alpha=2.3839, \beta=0.7258)$ fitted to the sample data.

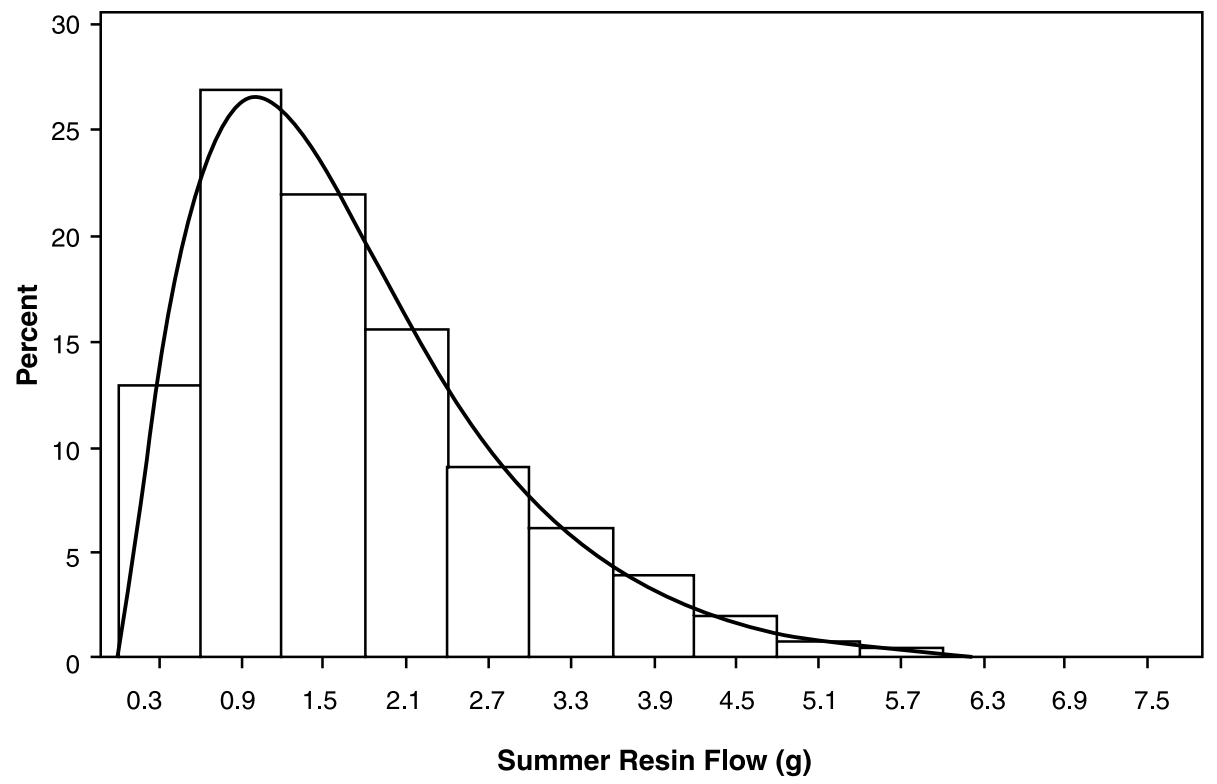

and that environmental effects have greater influence than dominance genetic effects.

Narrow-sense heritability estimates are moderately high for all traits (0.44 to 0.59 ) with values observed for resin yield being comparable to those found for the growth traits. Summer resin flow has the highest estimate, while the lowest value was recorded for spring resin flow. Estimates for the growth traits $(0.48$ to 0.53$)$ fall between these two extremes. Consistent with the lower values for dominance variance compared with additive variance, estimates for $D$ are mostly much smaller than estimates for heritability, with a single exception occurring for spring resin flow. In that case, the estimate for $D$ is one-half that of heritability, a larger ratio than found for the other traits, but one that reflects the proportionally greater dominance variance observed for this trait.

Additive and dominance coefficients of variation are higher for the oleoresin flow traits than for the growth traits. This pattern is similar to that observed for total variability (Table 1) and indicates that the resin flow traits have higher components of genetic variation in addition to greater overall variability. Moreover, comparison of environmental and 
Table 3. Estimates of variances and derivative genetic parameters.

\begin{tabular}{lllllllrrr}
\hline Trait & $\hat{\sigma}_{\mathrm{A}}^{2}$ & $\hat{\sigma}_{\mathrm{D}}^{2}$ & $\hat{\sigma}_{\mathrm{E}}^{2}$ & $\hat{\sigma}_{\mathrm{P}}^{2}$ & $\hat{h}^{2}(\mathrm{SE})$ & $\hat{D}(\mathrm{SE})$ & $\hat{H}$ & $\mathrm{CV}_{\mathrm{A}}{ }^{*}$ & $\mathrm{CV}_{\mathrm{D}}{ }^{*}$ \\
\hline Summer resin flow & 0.6017 & 0.0382 & 0.3716 & 1.0115 & $0.59(0.11)$ & $0.04(0.07)$ & 0.63 & 54.2 & 13.7 \\
Spring resin flow & 0.6156 & 0.3018 & 0.4750 & 1.3924 & $0.44(0.12)$ & $0.22(0.12)$ & 0.66 & 43.3 & 30.3 \\
Total height & 0.5831 & 0.1349 & 0.4950 & 1.2130 & $0.48(0.11)$ & $0.11(0.09)$ & 0.59 & 6.5 & 3.1 \\
DBH & 3.7296 & 0.3504 & 3.5604 & 7.6404 & $0.49(0.10)$ & $0.05(0.08)$ & 0.53 & 11.1 & 3.4 \\
Volume & 0.001092 & 0.000098 & 0.000890 & 0.002080 & $0.53(0.10)$ & $0.05(0.07)$ & 0.57 & 26.4 & 7.9 \\
\hline
\end{tabular}

Note: $\hat{\sigma}_{\mathrm{A}}^{2}$, estimate of additive genetic variance; $\hat{\sigma}_{\mathrm{D}}^{2}$, estimate of dominance genetic variance; $\hat{\sigma}_{\mathrm{E}}^{2}$, estimate of environmental variance; $\hat{\sigma}_{\mathrm{P}}^{2}$, estimate of phenotypic variance; $\hat{h}^{2}$, estimate of narrow-sense heriability; $\hat{D}$, estimate of ratio of dominance to phenotypic variance; $\hat{H}$, estimate of broad-sense heritability; $\mathrm{CV}_{\mathrm{A}}$, estimate of additive genetic coefficient of variation; $\mathrm{CV}_{\mathrm{D}}$, estimate of dominance genetic coefficient of variation; $\mathrm{SE}$, standard error of estimate.

*Computed with means adjusted to an age 10 base.

phenotypic components of variability reveals that environmental effects influenced phenotypic variance slightly less in the resin flow traits than in the growth traits.

Despite having very close estimates for additive variance, the two resin flow traits display different partitions for the genetic complement of phenotypic variance. While dominance variance for summer resin yield was found to be negligible, the dominance component for spring resin yield was estimated to be approximately half the additive component and thus must be considered an important contribution to phenotypic variance. This difference is clearly reflected in the varying estimates for $h^{2}$ and $D$ obtained for the two traits.

\section{Correlation estimates}

Additive genetic correlations between resin yield and growth traits are positive and moderate in size (Table 4). Highest values occur for trait combinations involving summer flow, although those involving spring resin flow are only slightly smaller. As expected from results of previous studies (Bridgwater et al. 1983; Gwaze et al. 2001), genetic correlations between the growth traits are positive and high: $r_{\mathrm{A}}=0.89$ between total height and $\mathrm{DBH}$, and $r_{\mathrm{A}}=0.93$ between total height and volume. Likewise, spring and summer resin flow are found to have a high, positive genetic correlation $\left(r_{\mathrm{A}}=0.89\right)$. This is not altogether surprising, since spring samples were collected in the spring of 2000 following collection of summer samples in late summer of 1999 and probably reflect draining of similar resin stores.

Phenotypic correlations, while positive, are somewhat smaller than the genetic correlations. Values for resin yield and growth trait combinations tend to be low with the smallest values occurring between trait pairs that include spring resin flow. These combinations have correlation estimates close to zero, while estimates for pairs involving summer resin flow are slightly higher, reaching the neighborhood of 0.25 . On the other hand, phenotypic correlations between total height and DBH and total height and volume are much larger, as is the correlation between summer and spring resin flow.

In contrast to genetic and phenotypic correlations, estimates for environmental correlations between the resin yield and growth traits are negative. Estimates between summer resin yield and the growth traits are marginally negative and probably do not statistically differ from zero, but values obtained between spring flow and growth are more strongly negative and likely reflect true, but weak, negative associa-
Table 4. Estimates of additive genetic $\left(r_{\mathrm{A}}\right)$, phenotypic $\left(r_{\mathrm{P}}\right)$, and environmental $\left(r_{\mathrm{E}}\right)$ correlations.

\begin{tabular}{lllr}
\hline Trait combination & $r_{\mathrm{A}}(\mathrm{SE})$ & $r_{\mathrm{P}}(\mathrm{SE})$ & \multicolumn{1}{c}{$r_{\mathrm{E}}$} \\
\hline Sum RF - Spr RF & $0.89(0.06)$ & $0.58(0.03)$ & 0.11 \\
Sum RF - THt & $0.67(0.12)$ & $0.23(0.05)$ & -0.17 \\
Sum RF - DBH & $0.58(0.13)$ & $0.25(0.05)$ & -0.05 \\
Sum RF - Vol & $0.59(0.12)$ & $0.26(0.05)$ & -0.05 \\
Spr RF - THt & $0.62(0.14)$ & $0.13(0.05)$ & -0.32 \\
Spr RF - DBH & $0.49(0.16)$ & $0.09(0.05)$ & -0.36 \\
Spr RF - Vol & $0.51(0.15)$ & $0.10(0.05)$ & -0.34 \\
THt-DBH & $0.89(0.06)$ & $0.62(0.03)$ & 0.37 \\
THt-Vol & $0.93(0.04)$ & $0.73(0.02)$ & 0.49 \\
\hline
\end{tabular}

Note: Sum RF, summer resin flow; Spr RF, spring resin flow; THt, total height; DBH, diameter at breast height; Vol, tree volume.

tions. Negative environmental correlations such as these imply that microenvironmental factors exist that conversely affect individual tree growth and resin flow. Environmental correlation estimates for the remaining trait pairs are positive with values representing associations between growth traits reaching moderate size.

\section{Discussion}

Our results conclusively demonstrate that constitutive oleoresin flow in young loblolly pine is under strong genetic control. Values obtained for both heritabilities and the genetic coefficients of variation strongly imply that genetic effects are significantly active in regulating resin flow. They further suggest, both for spring and summer resin yield, that additive genetic variance is the prevalent form of genetic variation occurring among individual trees. These findings are consistent with those of Nebeker et al. (1992), who found large differences in total resin flow among full-sib families of loblolly pine, and those of Strom et al. (2002), who reported greater constitutive resin flow in progeny of loblolly pines that remained alive in stands devastated by SPB. Our estimates for narrow-sense heritabilities in total flow also closely agree with the value of 0.55 reported for gum resin yield in slash pine (Squillace and Bengston 1961). These results suggest that breeding efforts to increase resin flow through directional selection as advocated in Nebeker et al. (1992) should be successful.

Our heritability estimates for resin flow are moderately high, as are our estimates for height, DBH, and volume. The growth trait values correspond well with those assessed in 
some tests of comparable age (Gwaze et al. 1997, 2001), but are somewhat higher than those reported for loblolly pine in most other tests undertaken in southern United States (Bridgwater et al. 1983; Foster 1986; Balocchi et al. 1993; Xiang 2000; Gwaze et al. 2001). This disparity could result from of a variety of causes, but differences in within-site environmental heterogeneity are a likely contributing factor. Because our test site was formerly a cultivated field, it is expected to have greater environmental uniformity than many forest sites. Lopez-Upton et al. (1999) describe differences in heritability for height growth in young pines caused by differences in environmental variability associated with cultural conditions. Their intensive culture treatment resulted in lower environmental variation and, as a consequence, higher heritability. This was true even though lower additive genetic variance was also observed under intensive culture. Similarly, our relatively high heritabilities could at least partially be a reflection of lower environmental variability at our test site.

Our findings indicate that tree resin yields assessed at breast height in young loblolly pine tend to be distributed approximately as gamma random variables and thus have asymmetrical distributions skewed toward the right. Similar skewed distributions have been observed for oleoresin yields in slash pine (Squillace 1966; Peters 1971). Characters expressed as the result of a large number of independent, multiplicative factors are known to have such positively skewed distributions (Wright 1968; Lynch and Walsh 1998). Because resin flow displays this distributional form, it is possible that a sizeable number of interacting multiplicative components are involved in its expression. If this is the case, it is likely that expression of resin yield is controlled by large numbers of interacting genes.

We found that resin flow measured in the summer and the following spring had almost identical levels of additive variance and a high additive genetic correlation. Such concordance implies that these traits probably are affected to a large degree by the same complement of genes. The two traits, however, differ with respect to amounts of dominance genetic variance, with spring flow having the larger component. This contrasting pattern of variability suggests that additional genes not involved in influencing summer resin flow might affect resin yields during earlywood formation. Further research involving precise determination of dominance genetic variance in additional populations and environments is needed to determine whether the dissimilar patterns of genetic variability we observed are broadly consistent over a variety of conditions.

The positive, moderately high additive genetic correlations that occurred between the resin flow and the growth traits indicate that genetic factors are acting within individuals to concurrently increase (or decrease) resin yield and growth. While further experimentation is required to determine whether pleiotropy or gametic disequilibrium is responsible for these associations, a reasonable hypothesis is that they exist because of pleiotropy. Squillace (1966) similarly hypothesized that this mechanism causes the positive association found for growth and resin yield in slash pine. Pleiotropy, behavior in which individual genes affect more than one trait, is believed to be widespread and the cause of most genetic correlations (Falconer and Mckay 1996; Wright
1968). Selection on one trait of a pair that is constrained by a genetic correlation caused by pleiotropic effects will also elicit a response in the unselected trait. Since the correlations we report here are probably of this nature, truncation selection to improve growth in loblolly pine is expected to result in increased resin production. Thus breeding programs directed at increasing tree growth should also produce trees that are less likely to succumb to attack by SPB. Nevertheless, for optimal improvement of composite merit involving both defense and growth traits, a selection index approach should be adopted that includes resin flow as a focus for selection along with tree growth.

In view of the implied trade-offs between growth and resin formation, correlations between growth and resin production might always be expected to be negative. Results reported by van Noordwijk and de Jong (1986), however, prove that positive correlations are possible between characters influenced by resource allocation trade-offs. Such correlations can occur if individual variation in resource acquisition ability is considerably greater than variation in proportion of resources allocated to the traits. Houle (1991) extended treatment of resource acquisition and allocation processes to a genetic model involving pleiotropic effects. He demonstrated that positive genetic correlations are also possible when the number of genes that influence resource acquisition greatly exceeds the number that affect resource allocation, provided genetic variation for acquisition and allocation is maintained. These findings and our estimates that indicate positive genetic correlations exist between resin flow and growth traits suggest that genes influencing acquisition of resources have a much larger effect on the relationship between these traits than genes controlling allocation of photosynthates. This further suggests that acquisition processes and resource availability are significant factors governing variation in production of constitutive resin in loblolly pine, and clearly, at least for some conditions, that they have larger impact on quantities of resin produced than allocation processes.

\section{Acknowledgments}

The authors thank International Paper Company for access to their experimental plots, Greg Leach of International Paper Company for many helpful consultations, and Rod Kindlund of the Southern Research Station, U.S. Forest Service, for drafting the figure. We are grateful to Dr. John Monahan of North Carolina State University for assistance with statistical computing, and to Lynn Lott, Gay Flurry, and Chris Steiner for assistance with fieldwork. We also thank Dr. Bailian Li, Dr. Kier Klepzig, two anonymous referees, and the Associate Editor for comments and suggestions on earlier versions of the manuscript.

\section{References}

Balocchi, C.E., Bridgwater, F.E., Zobel, B.J., and Jahromi, S. 1993. Age trends in genetic parameters for tree height in a nonselected population of loblolly pine. For. Sci. 39: 231-251.

Blanche, C.A., Lorio, P.L., Jr., Sommers, R.A., Hodges, J.D., and Nebeker, T.E. 1992. Seasonal cambial growth and development 
of loblolly pine: xylem formation, inner bark chemistry, resin ducts, and resin flow. For. Ecol. Manage. 49: 151-165.

Braaten, M.O. 1965. The union of partial diallel mating designs and incomplete block environmental designs. North Carolina State University, Raleigh, N.C. Inst. Stat. Mimeogr. Ser. 432.

Bridgwater, F.E., Talbert, J.T., and Jahromi, S. 1983. Index selection for increased dry weight in a young loblolly pine population. Silvae Genet. 32: 157-161.

Cook, S.P., and Hain, F.P. 1987. Susceptibility of trees to southern pine beetle, Dendroctonus frontalis (Coleoptera: Scolytidae). Environ. Entomol. 16: 9-14.

Coyne, J.F., and Lott, L.H. 1976. Toxicity of substances in pine oleoresin to southern pine beetles. J. Georgia Entomol. Soc. 11: 301-305.

Falconer, D.S., and Mackay, T.F.C. 1996. Introduction to quantitative genetics. 4th ed. Longman Group Limited, Harlow, U.K.

Foster, G.S. 1986. Trends in genetic parameters with stand development and their influence on early selection for volume growth in loblolly pine. For. Sci. 32: 944-959.

Gilmour, A.R. 1996. ASREML, a spatial REML program. Mimeograph report. New South Wales Agriculture, Orange, New South Wales, Australia.

Gilmour, A.R., Cullis, B.R., Welham, S.J., and Thompson, R. 1999. ASREML reference manual. New South Wales Agriculture, Orange, New South Wales, Australia.

Gwaze, D.P., Woolliams, J.A., and Kanowski, P.J. 1997. Genetic parameters for height and stem straightness in Pinus taeda Linnaeus in Zimbabwe. For. Genet. 4: 159-169.

Gwaze, D.P., Bridgwater, F.E., Byram, T.D., and Lowe, W.J. 2001. Genetic parameter estimates for growth and wood density in loblolly pine (Pinus taeda L.). For. Genet. 8: 47-55.

Gwaze, D.P., Harding, K.J., Purnell, R.C., and Bridgwater, F.E. 2002. Optimum selection age for wood density in loblolly pine. Can. J. For. Res. 32: 1393-1399.

Hodges, J.D., Elam, W.W., Watson, W.F., and Nebeker, T.E. 1979. Oleoresin characteristics and susceptibility of four southern pines to southern pine beetle (Coleoptera: Scolytidae) attacks. Can. Entomol. 111: 889-896.

Houle, D. 1991. Genetic covariance of fitness correlates: what genetic correlations are made of and why it matters. Evolution, 45: 630-648.

Houle, D. 1992. Comparing evolvability and variability of quantitative traits. Genetics, 130: 195-204.

Huber, D.A. 1993. Optimal mating designs and optimal techniques for analysis of quantitative traits in forest genetics. Ph.D. dissertation, University of Florida, Gainesville, Fla.

Kempthorne, O., and Curnow, R.N. 1961. The partial diallel cross. Biometrics, 17: 229-250.

Loomis, W.E. 1932. Growth-differentiation balance vs. carbohydratenitrogen ratio. Proc. Am. Soc. Hort. Sci. 29: 240-245.

Lombardero, M.J., Ayres, M.P., Lorio, P.L., Jr., and Ruel, J.J. 2000. Environmental effects on constitutive and inducible resin defences of Pinus taeda. Ecol. Lett. 3: 329-339.

Lopez-Upton, J., White, T.L., and Huber, D.A. 1999. Effects of site and intensive culture on family differences in early growth and rust incidence of loblolly and slash pine. Silvae Genet. 48: 284293.

Lorio, P.L., Jr. 1986. Growth-differentiation balance: a basis for understanding southern pine beetle-tree interactions. For. Ecol. Manage. 14: 259-273.
Lorio, P.L., Jr., Sommers, R.A., Blanche, C.A., Hodges, J.D., and Nebeker, T.E. 1990. Modeling pine resistance to bark beetles based on growth and differentiation balance principles. In Process modeling of forest growth responses to environmental stress. Edited by R.K. Dixon, R.S. Meldahl, G.A. Ruark, and W.G. Warren. Timber Press, Portland, Ore. pp. 402-409.

Lynch, M., and Walsh, B. 1998. Genetics and analysis of quantitative traits. Sinauer Associates, Inc., Sunderland, Mass.

McReynolds, R.D., and Gansel, C.R. 1985. High-gum-yielding slash pine: Performance to age 30. South. J. Appl. For. 9: 29-32.

Nebeker, T.E., Hodges, J.D., Honea, C.R., and Blanche, C.A. 1988. Preformed defensive system in loblolly pine: variability and impact on management practices. In Proceedings of the IUFRO Working Party and XVII International Congress of Entomology Symposium, Integrated Control of Scolytid Bark Beetles, 4 July 1988, Vancouver, B.C. Edited by T.L. Payne and H. Saarenmaa. VPI Press, Blacksburg, Va. pp. 147-162.

Nebeker, T.E., Hodges, J.D., Blanche, C.A., Honea, C.R., and Tisdale R.A. 1992. Variation in the constitutive defensive system of loblolly pine in relation to bark beetle attack. For. Sci. 38: 457-466.

Peters, W.J. 1971. Variation in oleoresin yielding potential of selected slash pines. For. Sci. 17: 306-307.

Popp, M.P., Johnson, J.D., and Massey, T.L. 1991. Stimulation of resin flow in slash and loblolly pine by bark beetle vectored fungi. Can. J. For. Res. 21: 1124-1126.

Reeve, J.R., Ayers, M.P., and Lorio, P.L., Jr. 1995. Host suitability, predation, and bark beetle population dynamics. In Population dynamics: new approaches and synthesis. Edited by N. Cappuccino and P.W. Price. Academic Press, San Diego, Calif. pp. 339-357.

Schmitt, D., and Bower, D. 1970. Volume tables for young loblolly, slash, and longleaf pines in plantations in south Mississippi. U.S. For. Serv. Res. Note. SO-102.

Squillace, A.E. 1966. Combining superior growth and timber quality with high gum yield in slash pine. Proc. South. For. Tree Improv. Conf. 8. pp. 73-76.

Squillace, A.E., and Bengston, G.W. 1961. Inheritance of gum yield and other characteristics of slash pine. Proc. South. For. Tree Improv. Conf. 6. pp. 85-96.

Strom, B.L., Goyer, R.A., Ingram, L.L., Jr., Boyd, G.D.L., and Lott, L.H. 2002. Oleoresin characteristics of progeny of loblolly pines that escaped attack by the southern pine beetle. For. Ecol. Manage. 158: 169-178.

Tadesse, W., Nanos, N., Auñon, F.J., Alfa, R., and Gil, L. 2001. Evaluation of high resin yielders of Pinus pinaster AIT. For. Genet. 8: 271-278.

van Noordwijk, A.J., and de Jong, G. 1986. Acquisition and allocation of resources: their influence on variation in life history tactics. Am. Nat. 128: 137-142.

Wilkens, R.T., Ayres, M.P., Lorio, P.L., Jr., and Hodges, J.D. 1998. Environmental effects on pine tree carbon budgets and resistance to bark beetles. In The productivity and sustainability of southern forest ecosystems in a changing environment. Global change and disturbance in southern ecosystems. Edited by R.A. Mickler and S. Fox. Springer-Verlag, New York. pp. 591-616.

Wright, S. 1968. Evolution and the genetics of populations. Vol. 1. Genetic and biometric foundations. University of Chicago Press, Chicago, Ill.

Xiang, B. 2000. Genetic analysis of diallel tests of loblolly pine (Pinus taeda L.). Ph.D. dissertation, North Carolina State University, Raleigh, N.C. 